\title{
The Expression of BTS-2 Enhances Cell Growth and Invasiveness in Renal Cell Carcinoma
}

\author{
QUOC THANG PHAM $^{1}$, NAOHIDE OUE ${ }^{1}$, YUJI YAMAMOTO ${ }^{1}$, YOSHINORI SHIGEMATSU $^{1,2}$, \\ YOHEI SEKINO $^{1,2}$, NAOYA SAKAMOTO ${ }^{1}$, KAZUHIRO SENTANI $^{1}$, \\ NAOHIRO URAOKA ${ }^{3}$, MAMATA TIWARI ${ }^{4}$ and WATARU YASUI ${ }^{1}$ \\ ${ }^{1}$ Department of Molecular Pathology, Hiroshima University \\ Institute of Biomedical and Health Sciences, Hiroshima, Japan; \\ ${ }^{2}$ Department of Urology, Hiroshima University Institute of Biomedical and Health Sciences, Hiroshima, Japan; \\ ${ }^{3}$ Department of Translational Molecular Pathology, \\ The University of Texas MD Anderson Cancer Center, Houston, TX, U.S.A.; \\ ${ }^{4}$ Department of Pathology, Chitwan Medical College Teaching Hospital, Chitwan, Nepal
}

\begin{abstract}
Background: Renal cell carcinoma (RCC) is one of the most common types of cancer in developed countries. Bone marrow stromal cell antigen 2 (BST2) gene, which encodes BST2 transmembrane glycoprotein, is overexpressed in several cancer types. In the present study, we analyzed the expression and function of BST2 in RCC. Materials and Methods: BST2 expression was analyzed by immunohistochemistry in 123 RCC cases. RNA interference was used to inhibit BST2 expression in a RCC cell line. Results: Immunohistochemical analysis showed that $32 \%$ of the 123 RCC cases were positive for BST2. BST2 expression was positively associated with tumour stage. Furthermore, BST2 expression was an independent predictor of survival in patients with RCC. BST2 siRNA-transfected Caki-1 cells displayed significantly reduced cell growth and invasive activity relative to negative control siRNA-transfected cells. Conclusion: These results suggest that BST2 plays an important role in the progression of RCC. Because BST2 is expressed on the cell membrane, BST2 is a good therapeutic target for $R C C$.
\end{abstract}

According to WHO 2012, kidney cancer is one of the most common types of cancer in developed countries, representing the ninth most common cancer in men and the 14th most common in women worldwide (1). More than $90 \%$ of kidney cancers are is renal cell carcinomas (RCCs) (2). RCCs usually

Correspondence to: Dr. Naohide Oue, MD, Ph.D., Department of Molecular Pathology, Hiroshima University Institute of Biomedical and Health Sciences, 1-2-3 Kasumi, Minami-ku, Hiroshima 7348551, Japan. Tel: +81 822575146, Fax: +81 822575149, e-mail: naoue@hiroshima-u.ac.jp

Key Words: BST2, renal cell carcinoma, invasion, prognosis, EGFR. have asymptomatic clinical presentation and $25-30 \%$ of patients have advanced disease at the time of diagnosis (3). Although these carcinomas are commonly treated with surgical excision, the recurrence rate is about $20-30 \%$ in patients with localized tumours (4). The current first-line treatments for metastatic RCC are the vascular endothelial growth factor receptor tyrosine kinase inhibitors sunitinib and sorafenib (5). However, a recent randomized control clinical phase III trial demonstrated that adjuvant therapy with these drugs does not improve progression-free survival for patients with RCC (6). Therefore, it is crucial to identify new biomarkers in order to develop a novel therapeutic target.

The bone marrow stromal cell antigen 2 (BST2) gene, which encodes BST2 protein, is expressed in terminallydifferentiated B-cells and may be involved in early pre-Bcell development $(7,8)$. BST2 is a lipid raft-associated type 2 transmembrane glycoprotein that exhibits antivirus function and is also overexpressed in several cancer types (8). Among solid tumours, BST2 expression is elevated in head and neck cancer (9), lung cancer (10), breast cancer (8, 11, 12), endometrial cancer (13), myelomas (14), glioblastoma (15), oesophageal, gastric and colorectal cancer (16). BST2 overexpression could be involved in tumour progression and serves as an independent prognostic indicator in breast cancer as well as in oesophageal and gastric cancer $(8,16)$. Furthermore, BST2 activates natural killer cells and enhances the activity of a Food and Drug Administration-approved monoclonal antibody against BST2 by increasing antibody-dependent cellular cytotoxicity (17). However, the expression and biological significance of BST2 in RCC have not been investigated.

In the present study, we investigated the expression of BST2 in RCCs and analyzed the relationship between BST2 expression and clinicopathological characteristics of patients 
with RCC. We also evaluated the effects of BST2 knockdown using RNA interference (RNAi) of BST2 on cell growth activity and invasion activity in RCC cell lines.

\section{Materials and Methods}

Tissue samples. In a retrospective study design, 132 primary tumours were collected from patients diagnosed with RCC who underwent surgery between 1994 and 2012 at Hiroshima University Hospital (Hiroshima, Japan). All patients underwent curative resection. Only patients without preoperative radiotherapy or chemotherapy were enrolled in the study. Operative mortality was defined as death within 30 days of patients leaving the hospital; these patients were removed from the analysis. Postoperative follow-up was scheduled every 1, 2 or 3 months during the first 2 years after surgery and every 6 months thereafter unless more frequent follow-up was deemed necessary. Chest X-ray, chestabdominal computed tomographic scan and serum chemistry analysis were performed at every follow-up visit. Patients were followed by their physician until death or the date of the last documented contact. Tumour staging was determined according to the TNM classification system (18). This study was approved (No. IRINHI66) by the Ethical Committee for Human Genome Research of Hiroshima University (Hiroshima, Japan).

For quantitative reverse transcription-polymerase chain reaction (qRT-PCR), we used nine RCC samples. Tumour tissues and their corresponding non-neoplastic tissue were surgically removed, frozen immediately in liquid nitrogen, and stored at $-80^{\circ} \mathrm{C}$ until use.

For immunohistochemical analysis, we used archival formalinfixed, paraffin-embedded tissues from 123 patients who had undergone surgical excision for RCC. One or two representative tumour blocks, including the tumour centre, invading front, and tumour-associated non-neoplastic mucosa, from each patient were examined using immunohistochemistry. In cases of large, late-stage tumours, two different sections were examined to include representative areas of the tumour centre as well as of the lateral and deep tumour invasive fronts.

qRT-PCR analysis. Total RNA was extracted with an RNeasy Mini Kit (Qiagen, Valencia, CA, USA), and $1 \mu \mathrm{g}$ of total RNA was converted to cDNA using the First Strand cDNA Synthesis Kit (Amersham Biosciences, Piscataway, NJ, USA). Quantitation of BST2 mRNA level was performed by real-time fluorescence detection as described previously (19). PCR was conducted using the SYBR Green PCR Core Reagents Kit (Applied Biosystems; Thermo Fisher Scientific, Inc., Waltham, MA, USA). Real-time detection of the emission intensity of SYBR green bound to doublestranded DNA was performed with the ABI PRISM 7700 Sequence Detection System (Applied Biosystems). Actin-beta (ACTB)-specific PCR products were amplified from the same RNA samples and served as an internal control.

Immunohistochemistry. Immunohistochemical analysis was performed with the EnVision+ Rabbit Peroxidase Detection System (Dako Cytomation, Carpinteria, CA, USA) as described previously (20). A rabbit polyclonal antibody to BST2 was used as primary antibody (dilution, 1:50; catalogue no. HPA017060; Sigma, St. Louis, MO, USA). Immunostaining was considered positive if $\geq 10 \%$ of cancer cells were stained. When $<10 \%$ of cancer cells were stained, the immunostaining was considered negative.
Cell lines. Two cell lines derived from human kidney cancer (Caki-1 and 786) were purchased from the Japanese Collection of Research Bioresources Cell Bank (Osaka, Japan). Both cell lines were maintained in RPMI-1640 (Nissui Pharmaceutical Co, Ltd, Tokyo, Japan) containing $10 \%$ foetal bovine serum (BioWhittaker, Walkersville, MD, USA) in a humidified atmosphere of $5 \% \mathrm{CO} 2$ and $95 \%$ air at $37^{\circ} \mathrm{C}$.

Western blot analysis. Cells were lysed as described previously (21). The lysates $(40 \mu \mathrm{g})$ were solubilized in Laemmli sample buffer by boiling and then subjected to $10 \%$ sodium dodecyl sulfatepolyacrylamide gel electrophoresis followed by electrotransfer onto a nitrocellulose filter. Anti-BST2 was purchased from Sigma. Antiepidermal growth factor receptor (EGFR), anti-phospho-EGFR (pEGFR), anti-extracellular signal-regulated kinase 1/2 (ERK1/2), anti-phospho-ERK1/2 (pERK1/2), anti-AKT, and anti-phospho-AKT (pAKT) were purchased from Cell Signaling Technology (Danvers, MA, USA). Peroxidase-conjugated anti-rabbit IgG or anti-mouse $\mathrm{IgG}$ was used in the secondary reaction. Immunocomplexes were visualized with an ECL Western Blot Detection System (Amersham Biosciences). $\beta$-Actin (Sigma) was used as a loading control.

RNAi. Short interfering RNA (siRNA) oligonucleotides targeting $B S T 2$ and a negative control were purchased from Invitrogen (Carlsbad, CA, USA). We used two independent BST2 siRNA oligonucleotide sequences. Transfection was performed using Lipofectamine RNAiMAX (Invitrogen) as described previously (19). Briefly, 60 pmol of siRNA and $10 \mu \mathrm{l}$ of Lipofectamine RNAiMAX were mixed in $1 \mathrm{ml}$ of RMPI medium $(10 \mathrm{nmol} / \mathrm{l}$ final siRNA concentration). After $20 \mathrm{~min}$ of incubation, the mixture was added to cells and then cells were plated in culture dishes. Fortyeight hours after transfection, cells were analysed.

Cell growth assays. We performed 3-(4,5-dimethylthiazol-2-yl)-2,5diphenyltetrazolium bromide (MTT) assays as described previously (22). The cells were seeded at a density of 2,000 cells per well in 96-well plates. Cell growth was examined after 1, 2, and 4 days. Three independent experiments were performed. The mean and standard error (SE) were calculated for each experiment.

Cell invasion assays. Modified Boyden chamber assays were performed to examine cell invasiveness. Cells were plated at 10,000 cells per well in RPMI-1640 medium plus $1 \%$ serum in the upper chamber of a Transwell Insert $(8 \mu \mathrm{m}$ pore diameter; Chemicon, Temecula, CA, USA) coated with Matrigel. Medium containing $10 \%$ serum was added in the bottom chamber. After 2 days, cells in the upper chamber were removed by scraping, and the cells remaining on the lower surface of the insert were stained with CyQuant GR dye (Chemicon) to assess the number of cells. Three independent experiments were carried out. The mean and SE were calculated for each of the experiments.

Statistical methods. Associations between clinicopathological parameters and BST2 expression were analysed by Fisher's exact test. Kaplan-Meier survival curves were constructed for BST2positive and BST2-negative patients. Survival rates were compared between BST2-positive and BST2-negative groups. Differences between survival curves were tested for their statistical significance by a log-rank test. Differences between the two groups (BST2 siRNA-transfected cells and negative control siRNA-transfected cells) were tested by Student $t$-test. 


\section{Results}

Expression of BST2 in RCC. We first analyzed the expression of BST2 in nine RCC tissue samples and nine corresponding non-neoplastic tissue samples by qRT-PCR. We calculated the ratio of $B S T 2$ mRNA levels between tumour tissue (T) and corresponding non-neoplastic tissue $(\mathrm{N})$, and $\mathrm{T} / \mathrm{N}$ ratios $>2.0$ were considered to indicate an up-regulation. Of the nine RCC cases, expression of BST2 was up-regulated in four $(44 \%)$ (Figure 1A).

We next performed immunohistochemistry on 123 RCC tissue samples. In non-neoplastic tissue, glomerulus showed weak membranous staining of BST2 (Figure 1B). Other cells did not express BST2. In contrast, RCC tissue showed stronger, more extensive staining compared with nonneoplastic tissue (Figure 1B). BST2 staining was observed mainly on the tumour cell membrane (Figure 1C). Many RCC cases showed heterogeneity of BST2 staining, and the percentage of BST2-stained tumour cells ranged from 0 to $100 \%$. We did not observe any up-regulation of BST2 at the invasive front. In total, 39 (32\%) of 123 RCC cases were positive for BST2.

We next examined the relationship of BST2 staining with clinicopathological characteristics of the 123 patients with RCC (Table I). BST2 expression was associated with advanced $\mathrm{T}, \mathrm{N}$ and $\mathrm{M}$ classification, tumour stage and histological grade. These results suggested that BST2 plays an important role in the progression of RCC. Furthermore, Kaplan-Meier analysis demonstrated that BST2-positive RCC cases have poorer survival than BST2-negative RCC cases $(p<0.001$; Figure 1D). We next performed univariate and multivariate Cox proportional hazards analyses to evaluate the potential use of BST2 expression as a prognostic classifier (Table II). In univariate analysis, T, N and M classification, stage, histological classification, and BST2 expression were associated with poor survival. In the multivariate model, T, N and M classification, and BST2 expression were found to be independent predictors of survival in patients with RCC.

Effect of BST2 inhibition on cell growth and invasive activities. We next examined the effect of BST2 inhibition on cell growth and invasive activities using two different siRNAs. Caki-1 cells, which express high levels of BST2 protein, were selected for experimental analyses (Figure 2A). BST2 expression was substantially suppressed by treatment with siRNA1 and siRNA2 as shown by Western blotting (Figure 2B).

We first analyzed cell growth by MTT assays. As shown in Figure 2C, BST2 siRNA1- and siRNA2-transfected Caki-1 cells showed significantly reduced cell growth relative to negative control siRNA-transfected Caki- 1 cells ( $p<0.05$, Student $t$-test).

To determine the possible role of BST2 in invasiveness of RCC cells, we used modified Boyden chamber assays. On day
Table I. Relationship between bone marrow stromal cell antigen 2 (BST2) expression and clinicopathological characteristics in renal cell carcinoma.

\begin{tabular}{|c|c|c|c|}
\hline & \multicolumn{2}{|c|}{ BST2 expression, n (\%) } & \multirow[b]{2}{*}{$p$-Value } \\
\hline & Positive & Negative & \\
\hline \multicolumn{4}{|l|}{ Age } \\
\hline$\leq 65$ Years & $11(19)$ & $46(81)$ & 0.006 \\
\hline$>65$ Years & $28(42)$ & $38(58)$ & \\
\hline \multicolumn{4}{|l|}{ Gender } \\
\hline Female & $9(28)$ & $23(72)$ & 0.613 \\
\hline Male & $30(33)$ & $61(67)$ & \\
\hline \multicolumn{4}{|c|}{ Histological classification } \\
\hline $\mathrm{ccRCC}$ & $36(33)$ & $73(67)$ & 0.545 \\
\hline Non-ccRCC & $3(21)$ & $11(79)$ & \\
\hline \multicolumn{4}{|l|}{$\mathrm{T}$ classification } \\
\hline $\mathrm{T} 1 / 2$ & $17(22)$ & $60(78)$ & 0.003 \\
\hline $\mathrm{T} 3 / 4$ & $22(48)$ & $24(52)$ & \\
\hline \multicolumn{4}{|l|}{$\mathrm{N}$ classification } \\
\hline NO & $31(28)$ & $80(72)$ & 0.018 \\
\hline $\mathrm{N} 1 / 2$ & $8(67)$ & $4(33)$ & \\
\hline \multicolumn{4}{|l|}{ M classification } \\
\hline M0 & $21(22 \%)$ & $75(78)$ & $<0.001$ \\
\hline M1 & $18(67 \%)$ & $9(33)$ & \\
\hline \multicolumn{4}{|l|}{ Stage } \\
\hline $\mathrm{I} / \mathrm{II}$ & $14(19 \%)$ & $58(81)$ & 0.001 \\
\hline III/IV & $25(49 \%)$ & $26(51)$ & \\
\hline \multicolumn{4}{|c|}{ Histological grade } \\
\hline $1 / 2$ & $10(13 \%)$ & $68(87)$ & $<0.001$ \\
\hline $3 / 4$ & $29(64 \%)$ & $16(36)$ & \\
\hline
\end{tabular}

ccRCC: Clear cell renal cell carcinoma.

2, the invasiveness of BST2 siRNA1-transfected and siRNA2transfected Caki-1 cells was less than that of the negative control siRNA-transfected Caki- 1 cells $(p<0.05$, Student $t$-test; Figure 2D). However, as BST2 knockdown cells showed significantly reduced cell growth, the differences in cell number observed in the invasion assay could be caused by the reduced cell growth. These results suggest that BST2 stimulates cell growth and invasion in tumour cells.

Because EGFR activates the RAS-MEK-ERK and AKTPI3K pathways leading to cancer cell proliferation and survival (23), we next analyzed the effect of BST2 inhibition on EGFR signalling. The levels of phosphorylated EGFR, ERK and AKT were lower in BST2 siRNA1- and siRNA2transfected Caki-1 cells than in control cells (Figure 2B).

\section{Discussion}

We previously generated an Escherichia coli ampicillin secretion trap (CAST) library from a gastric cancer cell line and defined 16 genes that encode transmembrane proteins, including BST2 (16). We reported that BST2 expression is 
A

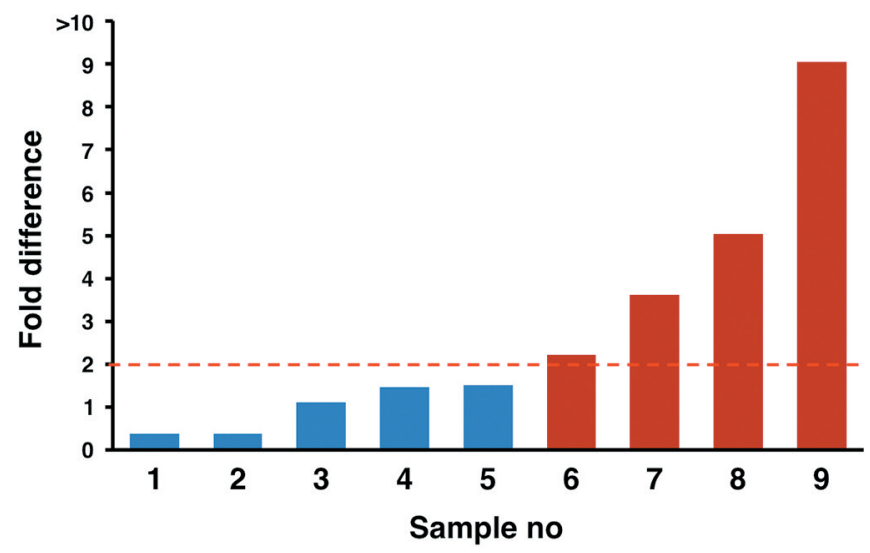

B

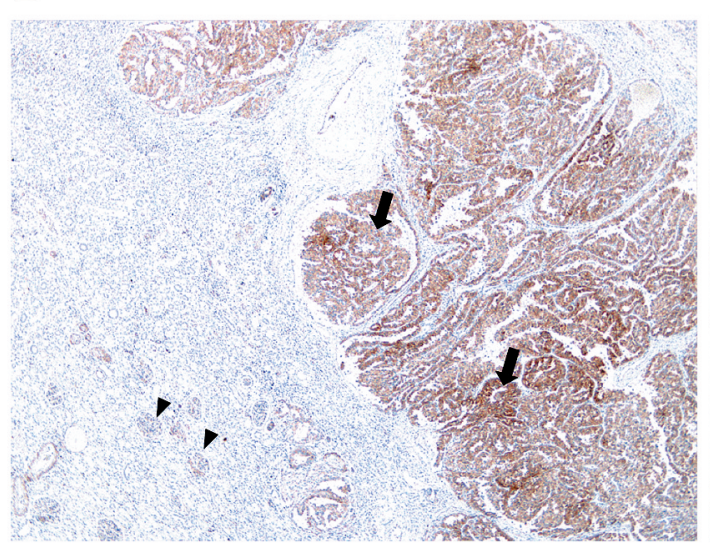

\section{C}
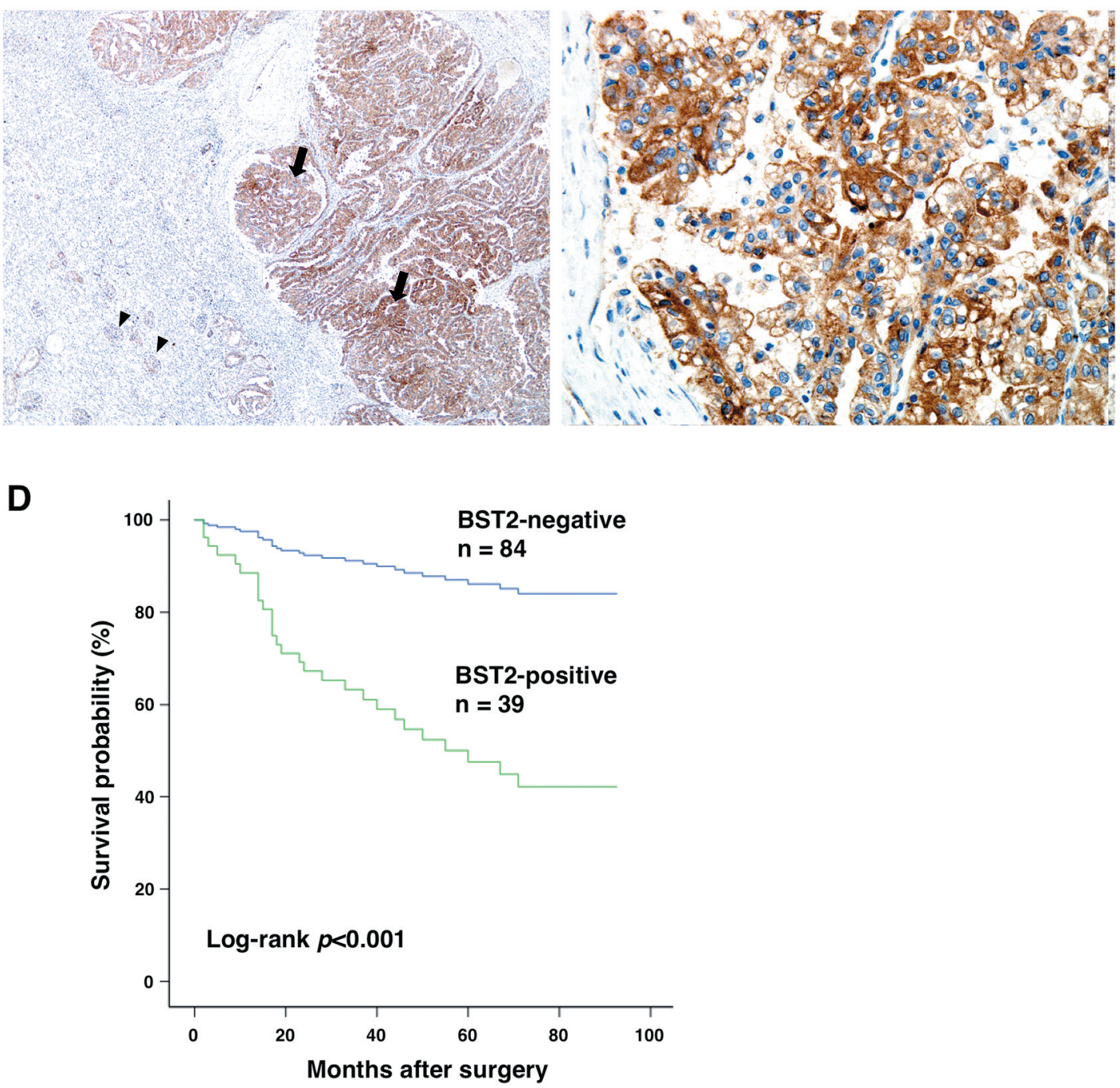

Figure 1. Expression of bone marrow stromal cell antigen 2 (BTS2) in renal cell carcinoma (RCC). A: Quantitative reverse transcription-polymerase chain reaction analysis of BST2 in nine RCC samples. The bars represent individual samples. Fold difference is the ratio of BST2 mRNA level in $R C C$ to that in corresponding non-neoplastic tissue. B: Immunohistochemical analysis of BST2 in RCC. Weak membranous staining in glomeruli (arrowhead) was observed, whereas strong BST2 staining was detected in RCC cells (arrow). Original magnification, $\times 40$. C: Immunohistochemical analysis of BST2 in RCC. Original magnification, x400. D: Kaplan-Meier plot of survival in patients with RCC by tumour BST2 expression. 

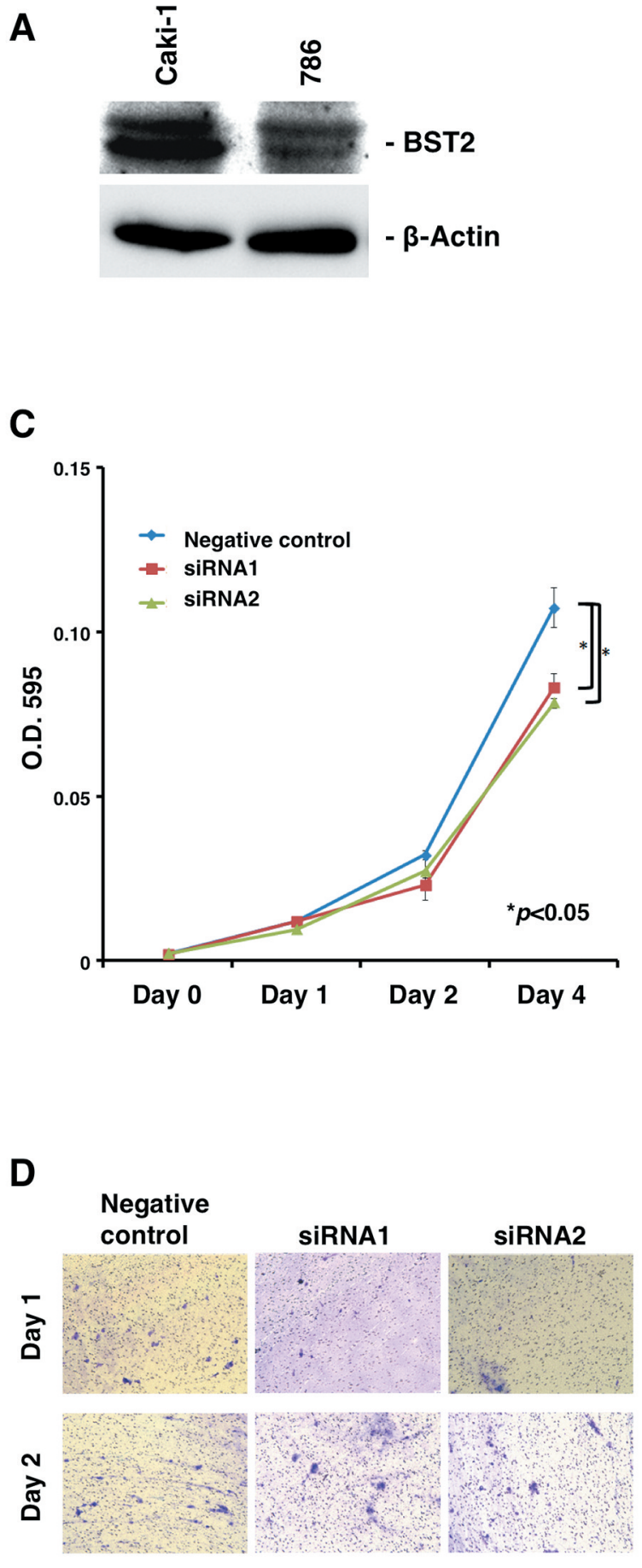

B

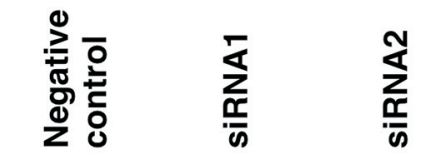

- BST2

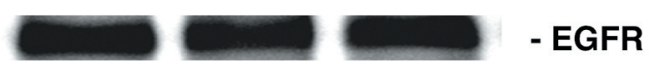

Penters

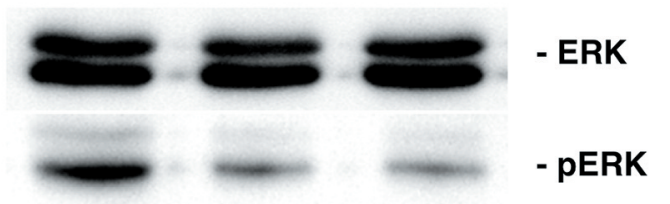

- AKT
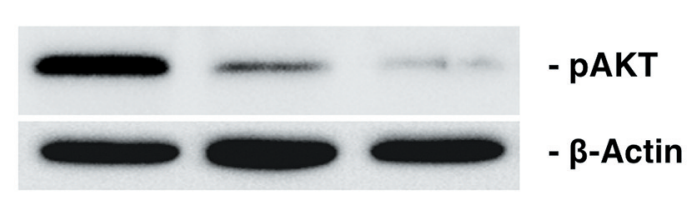

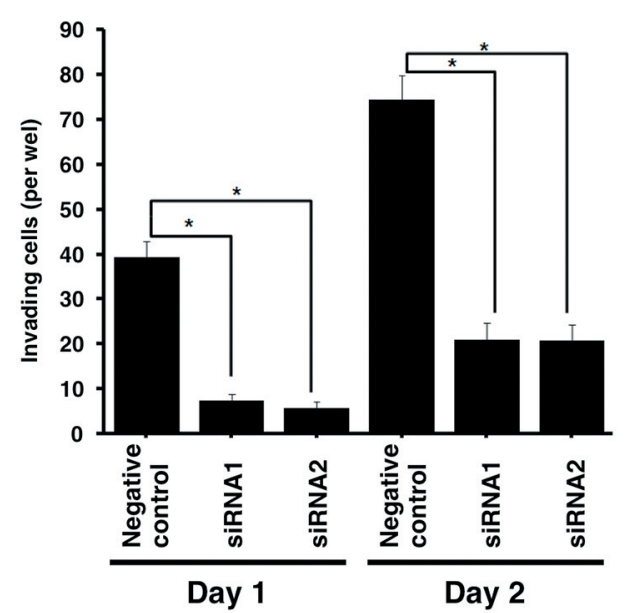

Figure 2. Effect of bone marrow stromal cell antigen 2 (BST2) inhibition in renal cell carcinoma (RCC). A: Western blot analysis of BST2 in two RCC cell lines. B: Western blot analysis of BST2, epidermal growth factor receptor (EGFR), phospho-EGFR ( EGFR), extracellular signal-regulated kinase 1/2 (ERK1/2), phospho-ERK1/2 (pERK1/2), AKT, and phospho-AKT (pAKT) in cell lysates from Caki-1 cells transfected with BST2 siRNA or negative control siRNA. $\beta$-Actin was included as a loading control. C: Effect of BST2 knockdown on cell growth of Caki-1 cells. Cell growth was assessed by 3-(4,5-dimethylthiazol-2-yl)-2,5-diphenyltetrazolium bromide assays at 1, 2, and 4 days after seeding on 96-well plates. D: Effect of BST2 knockdown on the invasiveness of Caki-1 cells as evaluated by modified Boyden chamber assays. Data are the mean \pm standard error (SE), respectively, of three experiments. *Significantly different at $p<0.05$. 
Table II. Univariate and multivariate Cox regression analysis of bone marrow stromal cell antigen 2 (BST2) expression and survival in renal cell carcinoma.

\begin{tabular}{|c|c|c|c|c|}
\hline \multirow[b]{2}{*}{ Characteristic } & \multicolumn{2}{|c|}{ Univariate analysis } & \multicolumn{2}{|c|}{ Multivariate analysis } \\
\hline & $\operatorname{HR}(95 \% \mathrm{CI})$ & $p$-Value & HR $(95 \% \mathrm{CI})$ & $p$-Value \\
\hline \multicolumn{5}{|l|}{ Age } \\
\hline$\leq 65$ Years & 1 (Ref.) & & & \\
\hline$>65$ Years & $1.28(0.61-2.68)$ & 0.516 & & \\
\hline \multicolumn{5}{|l|}{ Gender } \\
\hline Female & 1 (Ref.) & & & \\
\hline Male & $2.11(0.73-6.06)$ & 0.168 & & \\
\hline \multicolumn{5}{|c|}{ Histological classification } \\
\hline Non-ccRCC & 1 (Ref) & & & \\
\hline ccRCC & $0.85(0.26-2.82)$ & 0.792 & & \\
\hline \multicolumn{5}{|l|}{$\mathrm{T}$ Grade } \\
\hline $\mathrm{T} 1 / \mathrm{T} 2$ & 1 (Ref.) & & 1 (Ref.) & \\
\hline $\mathrm{T} 3 / \mathrm{T} 4$ & $18.32(6.33-53.05)$ & $<0.001$ & $6.23(1.36-28.47)$ & 0.018 \\
\hline \multicolumn{5}{|l|}{ N Grade } \\
\hline No & 1 (Ref.) & & 1 (Ref.) & \\
\hline $\mathrm{N} 1 / 2$ & $9.20(4.22-20.09)$ & $<0.001$ & $3.03(1.13-8.09)$ & 0.027 \\
\hline \multicolumn{5}{|l|}{ M Grade } \\
\hline M0 & 1 (Ref.) & & 1 (Ref.) & \\
\hline M1 & $14.71(6.71-32.26)$ & $<0.001$ & $3.07(1.23-7.65)$ & 0.016 \\
\hline \multicolumn{5}{|l|}{ Stage } \\
\hline $\mathrm{I} / \mathrm{II}$ & 1 (Ref.) & & 1 (Ref.) & \\
\hline $\mathrm{III} / \mathrm{IV}$ & $66.66(9.04-491.35)$ & $<0.001$ & $5.66(0.44-72.11)$ & 0.182 \\
\hline \multicolumn{5}{|c|}{ Histological grade } \\
\hline $1 / 2$ & 1 (Ref.) & & 1 (Ref.) & \\
\hline $3 / 4$ & $5.67(2.62-12.26)$ & $<0.001$ & $0.94(0.37-2.38)$ & 0.895 \\
\hline \multicolumn{5}{|c|}{ BST2 expression } \\
\hline Negative & 1 (Ref.) & & 1 (Ref.) & \\
\hline Positive & $4.97(2.36-10.47)$ & $<0.001$ & $2.52(1.04-6.08)$ & 0.040 \\
\hline
\end{tabular}

HR: Hazard ratio, CI: confidence interval, ccRCC: clear cell renal cell carcinoma, Ref: reference.

an independent prognostic factor for gastric cancer and oesophageal squamous cell carcinoma (16). In the present study, we examined the expression of BST2 in RCC. We found that BST2 expression was associated with tumour stage and histological grade. Kaplan-Meier analysis revealed that BST2-positive RCC cases have poorer survival than BST2-negative RCC cases, indicating that BST2 is involved in progression of RCC. Furthermore, both univariate and multivariate analysis demonstrated that BST2 expression was an independent prognostic factor in RCC. There results suggest that BST2 immunostaining is a clinically-useful method for the prediction of survival of patients with RCC.

We also evaluated the biological function of BST2 in RCC by inhibiting BST2 expression in Caki-1 cells. BST2 knockdown reduced cell proliferation and invasive activity of RCC cells. A previous study reported that BST2 expression is up-regulated in tamoxifen-resistant MCF-7 human breast cancer cells, resulting in enhanced invasiveness and migration (24). Although the precise biological functions of BST2 in tumourigenesis is not yet fully understood, another study showed that BST2 can enhance tumour cell invasion and metastasis through signal transducer and activator of transcription 3 (STAT3)/BST2/interleukin-6 pathway (24). In fact, STAT3 activation is an independent prognostic factor in RCC cases (25). Taken together, these results suggest that BST2 plays an important role in the progression of RCC.

A study in RCC xenograft models illustrated that interferon $\alpha$ (IFN $\alpha$ ) induced the expression of BST2 and treatment combining IFN $\alpha$ and antibody against BST2 presented more profound antitumour activity (26). A phase I clinical trial for an anti-BST2 in melanoma, RCC, ovarian cancer, and prostate cancer was launched in 2005 (27). However, the phase II clinical trial was withdrawn because of drug toxicity in 2009 (17). Since 2012, other anti-BST2 clinical trials in multiple combinatorial regimens have restarted (17). In the present study, functional analyses with 
RCC cells revealed that BST2 enhanced cell proliferation and invasiveness. In addition, BST2 expression was associated with poor survival. Therefore, BST2 could be a useful therapeutic target for RCC.

We showed that BST2 regulates the phosphorylation levels of EGFR, ERK, and AKT. A previous study revealed that phosphorylation of ERK and AKT results in inhibition of apoptosis (28), suggesting that apoptosis may also be inhibited in BST2 siRNA-transfected RCC cells. Taken together, these results demonstrate that BST2 participates in the activation of EGFR and suggest that EGFR signaling is important for RCC cell growth in BST2-positive cases.

In summary, the current study demonstrated that BST2 immunostaining is a clinically useful method for the prediction of survival of patients with RCC. Because BST2 suppression was involved with downstream signaling of EGFR pathway, BST2 may be not only a predicted marker, but also a novel therapeutic target in RCC. The efficacy of the humanized antiBST2 should be examined in a clinical study.

\section{Conflicts of Interest}

The Authors declare no conflicts of interest.

\section{Acknowledgements}

The present study was supported by Grants-in-Aid for Scientific Research (B-15H04713) and Challenging Exploratory Research (grant nos. 26670175 and 16K15247) from the Japan Society for the Promotion of Science, and by the Takeda Science Foundation.

\section{References}

1 Antoni S, Ferlay J, Soerjomataram I, Znaor A, Jemal A and Bray F: Bladder cancer incidence and mortality: a global overview and recent trends. Eur Urol 71: 96-108, 2017.

2 Kirkali Z, Cal C. In: Nargund VH, Raghavan D and Sandler HM (eds.): Urological Oncology. London, Springer, p. 263-280, 2008.

3 Gupta K, Miller JD, Li JZ, Russell MW and Charbonneau C: Epidemiologic and socioeconomic burden of metastatic renal cell carcinoma (mRCC): a literature review. Cancer Treat Rev 34: 193-205, 2008.

4 Motzer RJ, Agarwal N, Beard C, Bhayani S, Bolger GB, Carducci MA, Chang SS, Choueiri TK, Hancock SL, Hudes GR, Jonasch E, Josephson D, Kuzel TM, Levine EG, Lin DW, Margolin KA, Michaelson MD, Olencki T, Pili R, Ratliff TW, Redman BG, Robertson CN, Ryan CJ, Sheinfeld J, Spiess PE, Wang J and Wilder RB: Kidney cancer. J Natl Compr Canc Netw 9: 960-977, 2011.

5 Motzer RJ, Jonasch E, Agarwal N, Beard C, Bhayani S, Bolger GB, Chang SS, Choueiri TK, Costello BA, Derweesh IH, Gupta S, Hancock SL, Kim JJ, Kuzel TM, Lam ET, Lau C, Levine EG, Lin DW, Michaelson MD, Olencki T, Pili R, Plimack ER, Rampersaud EN, Redman BG, Ryan CJ, Sheinfeld J, Shuch B, Sircar K, Somer B, Wilder RB, Dwyer M and Kumar R: Kidney cancer, version 3.2015. J Natl Compr Canc Netw 13: 151-159, 2015.
6 Haas NB, Manola J, Uzzo RG, Flaherty KT, Wood CG, Kane C, Jewett M, Dutcher JP, Atkins MB, Pins M, Wilding G, Cella D, Wagner L, Matin S, Kuzel TM, Sexton WJ, Wong YN, Choueiri TK, Pili R, Puzanov I, Kohli M, Stadler W, Carducci M, Coomes $\mathrm{R}$ and DiPaola RS: Adjuvant sunitinib or sorafenib for high-risk, non-metastatic renal-cell carcinoma (ECOG-ACRIN E2805): a double-blind, placebo-controlled, randomised, phase 3 trial. Lancet 387: 2008-2016, 2016.

7 Goto T, Kennel SJ, Abe M, Takishita M, Kosaka M, Solomon A and Saito S: A novel membrane antigen selectively expressed on terminally differentiated human B-cells. Blood 84: 1922-1930, 1994.

8 Mahauad-Fernandez WD, Borcherding NC, Zhang W and Okeoma CM: Bone marrow stromal antigen 2 (BST2) DNA is demethylated in breast tumors and breast cancer cells. PLoS One 10: e0123931, 2015.

9 Fang KH, Kao HK, Chi LM, Liang Y, Liu SC, Hseuh C, Liao CT, Yen TC, Yu JS and Chang KP: Overexpression of BST2 is associated with nodal metastasis and poorer prognosis in oral cavity cancer. Laryngoscope 124: E354-360. 2014.

10 Wang W, Nishioka Y, Ozaki S, Jalili A, Abe S, Kakiuchi S, Kishuku M, Minakuchi K, Matsumoto T and Sone S: HM1.24 (CD317) is a novel target against lung cancer for immunotherapy using anti-HM1.24 antibody. Cancer Immunol Immunother 58: 967-976, 2009.

11 Mahauad-Fernandez WD, DeMali KA, Olivier AK and Okeoma CM: Bone marrow stromal antigen 2 expressed in cancer cells promotes mammary tumor growth and metastasis. Breast Cancer Res 16: 493, 2014

12 Sayeed A, Luciani-Torres G, Meng Z, Bennington JL, Moore DH and Dairkee SH: Aberrant regulation of the BST2 (Tetherin) promoter enhances cell proliferation and apoptosis evasion in high-grade breast cancer cells. PLoS One 8: e67191, 2013.

13 Yokoyama T, Enomoto T, Serada S, Morimoto A, Matsuzaki S, Ueda Y, Yoshino K, Fujita M, Kyo S, Iwahori K, Fujimoto M, Kimura $\mathrm{T}$ and Naka T: Plasma membrane proteomics identifies bone marrow stromal antigen 2 as a potential therapeutic target in endometrial cancer. Int J Cancer 132: 472-484, 2013.

14 Staudinger M, Glorius P, Burger R, Kellner C, Klausz K, Gunther A, Repp R, Klapper W, Gramatzki M and Peipp M: The novel immunotoxin HM1.24-ETA' induces apoptosis in multiple myeloma cells. Blood Cancer 4: e219, 2014.

15 Wainwright DA, Balyasnikova IV, Han Y and Lesniak MS: The expression of BST2 in human and experimental mouse brain tumors. Exp Mol Pathol 91: 440-446, 2011.

16 Mukai S, Oue N, Oshima T, Mukai R, Tatsumoto Y, Sakamoto N, Sentani K, Tanabe K, Egi H, Hinoi T, Ohdan H and Yasui W: Overexpression of transmembrane protein BST2 is associated with poor survival of patients with esophageal, gastric, or colorectal cancer. Ann Surg Oncol 24: 594-602, 2017.

17 Makkouk A, Chester C and Kohrt HE: Rationale for anti-CD137 cancer immunotherapy. Eur J Cancer 54: 112-119, 2016.

18 Sobin LH, Gospodarowicz MK and Wittekind CH (eds.): TNM Classification of Malignant Tumors, Seventh Edition. New York, Wiley-Liss, pp. 255-257, 2009.

19 Sakamoto N, Oue N, Sentani K, Anami K, Uraoka N, Naito Y, Oo HZ, Hinoi T, Ohdan H, Yanagihara K, Aoyagi K, Sasaki H and Yasui W: Liver-intestine cadherin induction by epidermal growth factor receptor is associated with intestinal differentiation of gastric cancer. Cancer Sci 103: 1744-1750, 2012. 
20 Oue N, Naito Y, Hayashi T, Takigahira M, Kawano-Nagatsuma A, Sentani K, Zarni Oo H, Uraoka N, Yanagihara K, Ochiai A, Sasaki $\mathrm{H}$ and Yasui W: Signal peptidase complex 18, encoded by SEC11A, contributes to progression via TGF-alpha secretion in gastric cancer. Oncogene 33: 3918-3926, 2014.

21 Yasui W, Ayhan A, Kitadai Y, Nishimura K, Yokozaki H, Ito H and Tahara E: Increased expression of p34CDC2 and its kinase activity in human gastric and colonic carcinomas. Int $\mathrm{J}$ Cancer 53: 36-41, 1993.

22 Alley MC, Scudiero DA, Monks A, Hursey ML, Czerwinski MJ, Fine DL, Abbott BJ, Mayo JG, Shoemaker RH and Boyd MR: Feasibility of drug screening with panels of human tumor cell lines using a microculture tetrazolium assay. Cancer Res 48: 589-601, 1988.

23 Li S, Schmitz KR, Jeffrey PD, Wiltzius JJ, Kussie P and Ferguson KM: Structural basis for inhibition of the epidermal growth factor receptor by cetuximab. Cancer Cell 7: 301-211, 2005.

24 Yi EH, Yoo H, Noh KH, Han S, Lee H, Lee JK, Won C, Kim $\mathrm{BH}, \mathrm{Kim} \mathrm{MH}$, Cho $\mathrm{CH}$ and Ye SK: BST2 is a potential activator of invasion and migration in tamoxifen-resistant breast cancer cells. Biochem Biophys Res Commun 435: 685-690, 2013.
25 Horiguchi A, Oya M, Shimada T, Uchida A, Marumo K and Murai M: Activation of signal transducer and activator of transcription 3 in renal cell carcinoma: a study of incidence and its association with pathological features and clinical outcome. J Urol 168: 762-765, 2002.

26 Kawai S, Azuma Y, Fujii E, Furugaki K, Ozaki S, Matsumoto T, Kosaka M and Yamada-Okabe H: Interferon-alpha enhances CD317 expression and the antitumor activity of anti-CD317 monoclonal antibody in renal cell carcinoma xenograft models. Cancer Sci 99: 2461-2466, 2008.

27 Molckovsky A and Siu LL: First-in-class, first-in-human phase I results of targeted agents: highlights of the 2008 American Society of Clinical Oncology Meeting. J Hematol Oncol 1: 20, 2008.

28 Takeuchi $\mathrm{K}$ and Ito F: EGF receptor in relation to tumor development: molecular basis of responsiveness of cancer cells to EGFR-targeting tyrosine kinase inhibitors. FEBS J 277: 316 326, 2010.

Received April 18, 2017

Revised May 2, 2017

Accepted May 8, 2017 